\title{
Editorial: Global citizenship education and the politics of conceptualization
}

\section{April R. Biccum* - Australian National University, Australia}

Much of the scholarship on global learning uses the Maastricht Declaration's 2002 definition:

Global Education is education that opens people's eyes and minds to the realities of the world and awakens them to bring about a world of greater justice, equity and human rights for all ... Global Education is understood to encompass Development Education, Human Rights Education, Education for Sustainability, Education for Peace and Conflict Prevention and Intercultural Education; being the global dimensions of Education for Citizenship. (Europe-wide Global Education Congress, 2002: 2)

This definition is used for good reason, since this multi-stakeholder meeting has been cited (Hartmeyer and Wegimont, 2016) as the beginning of a process of mainstreaming for global learning, in which the importance of raising public knowledge of aid, development, poverty and sustainability is increasingly recognized by international organizations such as the United Nations and the Organization for Economic Co-operation and Development (OECD) in multilateral processes such as the Millennium and Sustainable Development Goals, and by regional bodies such as the European Union. The Maastricht Congress saw the establishment of the first policymakers' platform on global learning, the Global Education Network (GENE). In its Development Assistance Committee-style peer-review process, GENE has paid particular attention to how global learning has been conceptualized by relevant national actors, recognizing the differences in national definition and the importance of conceptualization to the mainstreaming of global learning via national strategies. Thus, what we see is that conceptualization is an important part of political behaviour. Conceptualization is also an important part of political contestation, intimately linked to questions of ontologies, epistemologies, language and cognition. Global education, global learning and global citizenship are themselves meta-concepts predicated upon other loaded conceptual terms. As a set of multi-stakeholder, institutional and educator practices, global education (however defined and conceptualized) is predicated upon three issues central to the politics of knowledge in the social sciences: (1) ontology; (2) how actors know and understand their worlds; and (3) how social scientists know how the actors they study know and understand their worlds. In other words, in the context of unfolding world events in which there is much at stake in the politics of truth and knowledge (post-truth, fake news, and what you need to know to live in the world), it is vital at this juncture to situate global education in a wider discussion of the philosophy of science and the philosophy of language. This is precisely what these contributions to this special issue on conceptualizing global education have done, by elaborating developments in the philosophy of science such as critical realism (Khazem), analysing conceptual and discursive changes in the vocabulary of global education (Scoffham and Dillon), demonstrating that discursive critique gives rise to 
political debate and change (Bendix) and providing an analytic framework for thinking about actually existing poverty and inequality in the global economy (Gyoh).

It is fair to say that critical scholarship in the twentieth century was preoccupied by the relationship between knowledge and power. This is in part because the challenges of critical scholarship have pointed out the centrality of absolute truth claims garnered through scientific method in the social sciences to processes of division and dehumanization central to both metropolitan state building and territorial expansion. Critical scholarship has not been alone, however, in recognizing the problematic adoption of knowledge paradigms developed for the natural world into the study of the social world; even Friedrich Hayek (1945) and Hans Morgenthau (1946) have questioned the application of scientific method to the study of society. Twentiethcentury iterations of positivism presumed not only a mind-independent reality but cast aspersions on metaphysics and the ability of social scientists to know the minds of political actors and attempted to fix language and meaning for the purposes of scientific exactitude (Berlin, 1997). A wide variety of challenges emerged mid-century calling into question the existence of a mind-independent reality and brute data (Taylor, 1971), the ability of language and meaning to be fixed to referent objects (Derrida, 1993) and the social-scientific interrogation of thought and world view through the study of ideological, linguistic and discursive data and the carving out of new modes of empirical enquiry linked to a different set of epistemological and ontological assumptions. For instance, Frankfurt School critical theorists and Antonio Gramsci in the early part of the twentieth century focused scholarly attention on art, ideas, culture and mass communications as sites of politics with a concern for the capacity of mass culture and its hegemonic hold on the public sphere to stave off communist 'revolution' and mitigate public capacity to question the political order (Gramsci, 1971; Borg et al., 2002; Adorno, 1991). In other words, and with implications for critical scholarship on global citizenship education, the Frankfurt School and Gramsci were concerned with the capacity of dominant knowledge paradigms to inhibit political activism. The post-modernists of the 1960s, 1970s and 1980s articulated a new object: 'discourse' as a mode of meaning and knowledge production beyond academic disciplines and individual texts. Understanding knowledge as a mode of production, Michel Foucault (2010) further concretized the connection between knowledge and power and pioneered alternative methodological approaches, including discourse analysis (Jørgensen and Phillips, 2002). Discourse analysis and critical discourse analysis have become methodologies and fields in their own right, with the critical variant arguing that their purpose is to expose or unmask the biases and assumptions at work in discourses to show how they support structures of power with the aim of affecting political change through the dissemination of 'critical understanding' (van Dijk, 1993).

Interpretivism as a mode of enquiry has advanced methodology in the social sciences by engaging in and developing second-order observation (the observation of the observation). In the 1970s, the intersubjective was articulated as the realm of meaning-making and an object of knowledge that had not been considered before (Rabinow and Sullivan, 1979). Post-structuralists following Derrida challenged the philosophy of language and developed the methodology of deconstruction focused specifically on binary conceptual structures. Post-colonial scholars articulated the existence of modes of meaning and knowing required for colonial and imperial governance (colonial discourse), while decolonial scholars regard modernity as endemic to coloniality - a regime of knowledge responsible for 'epistemicide' of the knowledges of colonized people (de Souza Santos, 2007). Other modes of second-order observation have continued through the work of Bruno Latour (1987), 
who pioneered the field of science and technology studies, and the history of ideas (Skinner, 1969) and concepts (Koselleck, 2002) have emerged as important sub-fields. This list is by no means exhaustive, but in these developments three trends can be observed that are directly relevant for the study of global citizenship education. First, the field of knowledge production has become an object of knowledge itself, where scholars have engaged in a wide variety of second-order observation, with an emphasis on the materiality and ontological situatedness of knowledge production as 'in the world'. Second, in so doing, this scholarship has carved out new ontological and methodological terrain as language, concepts, discourses, ideas and meaning are regarded as central to social organization and the subjects of research have been understood as embedded in a web of meaning-making practices. Finally, a strong association has been made between knowledge production as a mode of power with the potential for violence, subordination, exploitation and exclusion, and the field of 'critical' knowledge production has been to expose this with the aim of transcending it. In other words, knowledge has become a site of politics, scholarship a field of activism.

These trends have a flipside. While scholars in the social sciences have battled over epistemological paradigms through the 'science wars' (Flyvbjerg, 2001), social scientists have a renewed confidence in their ability to make objective scientific claims because advances in information communications technology provide the capacity to collect large, high-quality data sets. For many social scientists, the existence of 'big data' has renewed an emphasis on quantification, scientific method and prediction for large-scale and aggregate patterns in human behaviour (Boyd and Crawford, 2012). Many around the world live in a 'scopic' economy, where the algorithms generated by our online activity produce a profile and the traceability of transactions provides vast amounts and new types of raw data that require new kinds of statistical methods to generate findings. The existence of this data has given rise to a widespread belief among social scientists that a new age of truth, objectivity and accuracy is upon us (Boyd and Crawford, 2012). It has led to new capabilities for the institutions of global governance to produce aggregate indices for the purposes of benchmarking for change. A computational turn in research has changed the terrain of knowledge production, but access to the data and capacity for analysis is often limited to the private sector actors who are producing it (Boyd and Crawford, 2012) or the international organizations whose members supply it and whose function in global governance has increasingly been to process and publish it. Interpretivist scholars engaged in secondorder observation have pointed to the 'seductions of quantification', demonstrating what is missed and masked by large-scale data sets and the politics of compiling indicators (Engle Merry, 2016).

We can call this a new politics of truth and knowledge, one that is directly relevant to global citizenship education as a mode of critical practice in education in many sites and that sees the creation of globally-minded, critical, globally-competent and active citizens as the solution to global problems. The contributions to this special issue engage in a robust discussion around the implications of the politics of truth and knowledge for global learning.

Dima Khazem's piece takes on directly the problematic for a type of learning that is predicated upon truth claims (that there is poverty and inequality in the world) on the part of critical scholars who want to engage themselves and build capacity among learners to engage in the questions of epistemology and ontology. Khazem offers critical realism as a compromise between positivism and interpretivism that will allow researchers and practitioners of global learning to bridge the tensions between a critical perspective that recognizes the link between knowledge and power while 
retaining the ability to predicate their critique on truth claims linked to issues of social injustice. This is done by organizing enquiry around three different presuppositions. One is characterized as 'ontological realism', which is the assumption that a real world exists independently of a knower's claims and understanding. The second is 'epistemological relativism', which is an acknowledgement that all knowledge of mindindependent reality is nevertheless socially produced under specific conditions. The third is to maintain 'judgemental rationality', that is, not falling prey to the notion that all knowledge claims and speech acts have equal worth and recognizing that there are good grounds for making choices between competing claims. Khazem's article rehearses and elaborates the contribution of critical realism and quite rightly suggests that its emphasis on ontological realism underwrites the necessary truth claims around poverty, injustice and inequality that global education is by its nature predicated upon.

Stephen Scoffham's piece engages more directly with global learning as a concept and argues that the evolving, ambiguous and unstable nature of this concept (indeed of all concepts) is both a weakness and a strength. Its weakness is that it leads to confusion and leaves global learning open to becoming little more than an 'empty signifier', to be filled up by all manner of different and perhaps competing (even antithetical) policies and practices - in other words, co-opting by more powerful actors. Yet that very undecidability is also the concept's strength, because it is required to promote the new ways of thinking that global learning has as its aim, and can act as a catalyst for wider curricular reform. Importantly, Scoffham's piece makes connections between the ontological nature of language (inexact and evolving) and emotions and cognition, which is precisely the space that global learning needs to engage creatively to create the capacity for change. In other words, if there is a link between language and cognition, the openness of the signifiers around global learning creates the space for a change in mindset. Given the emphasis that post-colonial scholars have placed on mindset and political domination, a change in mindset (a decolonization of the mind) for both colonizers and colonized is what is required for complete decolonization. Many critical scholars across the social sciences maintain that this work is not yet complete (Tuck and Yang, 2012; Ascione, 2016; Jones, 2006).

Daniel Bendix's piece carries on this discussion of the potentialities of global education for cognitive decolonization by conducting a discursive case analysis of development education policy in Germany. Bendix's piece is situated in the impact that post-colonial approaches have had on development education in Germany. He demonstrates how post-colonial critique can be applied in a discursive fashion to expose the assumptions in the German curriculum framework, but also elaborates how the framework became a site of discursive contestation whereby discursive analysis prompted public debate among development education stakeholders in Germany. Bendix's piece illustrates that learning does not just take place in the classroom and that discursive contestation can also be a site of politics in the public domain, with potentially more democratic outcomes, as the take-up of post-colonial approaches and the ensuing public debate has prompted changes to the curriculum framework.

The question of the discursive is carried on by Eilish Dillon's study of the discursive shift towards the 'global' in Irish development education, which she demonstrates is neither complete nor necessarily critical. Moving beyond textual analysis, Dillon's discourse analysis involved interview, text-based and ethnographic research to show that a change in vocabulary does not necessarily result in a change of discourse. This makes an important distinction between concepts and the underlying organizers of meaning, knowledge and reproduction that make up the semantic field in which they operate. Dillon's account of a layered understanding of discourse moves us beyond 
assuming a simple one-to-one relationship between language and cognition. It makes more concrete and empirically explicit how layered discourses work around the concepts of development and 'North-South', and therefore the educational work that needs to be done to truly decolonize development education. These are worthy contributions to a post-colonial discursive analysis of development education, but they rest, as Khazem's piece rightly points out, on ontological claims about power relations (the colonial) and their outcomes (poverty and inequality). These are whole fields of study (politics and economics) and contested terrain in their own right, which makes the work of critical global educators particularly difficult.

The final contribution in this special edition addresses directly this empirical question of poverty and inequality through an interdisciplinary approach that engages the actual patterns of distribution under globalization, which can no longer be framed in terms of the simple binaries of North and South, poor and rich, or by uncritically accepting the link between poverty and inequality. Instead, Son Gyoh offers an interdisciplinary intersectionality approach to the problem of inequality that draws the attention of scholars to spatial inequality, a paradigm concerned with the intersection of location and structure for locating actual patterns of poverty and inequality. Importantly, Gyoh's account draws our attention to the structures of knowledge production that are aggregated at state level and draw upon neoclassical economics for their understanding of poverty and inequality. He offers intersectionality as a paradigm that shows the complexity of economic and political interaction and intersection of structures and geographic spatiality in the global economy, which complicates our understanding of it but nevertheless provides an empirical account of the disproportionate concentration of poverty and wealth in less industrialized economies.

Gyoh's account of the ontology of poverty and inequality can be brought back around to the politics of truth and knowledge when it is remembered that our knowledge of national and global economies is produced in and through state and global and economic governance institutions, who routinely cite a lack of data, particularly for countries with precarious political situations, state fragility and therefore a lack of institutional capability to produce the statistics required to measure globalization. With no small irony, what is needed to measure globalization and therefore provide an accurate aggregate picture of poverty and inequality, is more globalization. This problematic is equally and no less paradoxically true for global education, where to know how to implement and spread best practice, global educators require statebased knowledge of the institutional capacity for global education (curricular and pedagogical frameworks, educational governance and accountability structures, teacher training capacity and so on). Again, with no small irony, what is needed for the spread of global education is a particular kind of state with similar national education systems. Future research in development education and global education needs to consider in more robust fashion the unfolding empirical dimensions of the global political and economic system. It needs to take a more robust account of global political trends that threaten to mitigate and halt the process of mainstreaming. Future special issues of this journal, therefore, will consider the state as the site and context for delivery and institutional capability for global education as well as the implications of emerging ethno-nationalisms and chauvinisms. 


\section{Notes on the contributor}

April Biccum is a lecturer in post-colonial international relations at the Australian National University. Her research brings post-colonial theory into the study of international relations with a focus on political communication and political mobilization in the study of empire and global citizenship, and the conceptualization and theorization of empire and imperialism and the politics of knowledge embedded in global citizenship education in particular.

\section{References}

Adorno, T.W. (1991) The Culture Industry: Selected essays on mass culture. London: Routledge.

Ascione, G. (2016) Science and the Decolonization of Social Theory: Unthinking modernity. London: Palgrave.

Berlin, I. (1997) 'Two concepts of liberty'. In Goodin, R.E. and Pettit, P. (eds) Contemporary Political Philosophy: An anthology. Oxford: Blackwell, 391-417.

Borg, C., Buttigieg, J. and Mayo, P. (eds) (2002) Gramsci and Education. Lanham, MD: Rowman \& Littlefield.

Boyd, D. and Crawford, K. (2012) 'Critical questions for big data: Provocations for a cultural, technological, and scholarly phenomenon'. Information, Communication and Society, $15(5), 662-79$.

Derrida, J. (1993) 'Structure, sign, and play in the discourse of the human sciences'. In Natoli, J. and Hutcheon, L. (eds) A Postmodern Reader. Albany, NY: State University of New York Press, 223-42.

de Sousa Santos, B. (2007) 'Beyond abyssal thinking: From global lines to ecologies of knowledges'. Eurozine, 29 June. Online. www.eurozine.com/articles/2007-06-29-santos-en.html (accessed 15 November 2012).

Engle Merry, S. (2016) The Seductions of Quantification: Measuring human rights, gender violence, and sex trafficking. Chicago: University of Chicago Press.

Europe-wide Global Education Congress (2002) Maastricht Global Education Declaration. Online. https://rm.coe.int/CoERMPublicCommonSearchServices/DisplayDCTMContent?documentld=09 0000168070 e540 (accessed 10 September 2018).

Flyvbjerg, B. (2001) Making Social Science Matter: Why social inquiry fails and how it can succeed again. Trans. Sampson, S. Cambridge: Cambridge University Press.

Foucault, M. (2010) The Archaeology of Knowledge and the Discourse on Language. Trans. Sheridan Smith, A.M. New York: Vintage Books.

Gramsci, A. (1971) Selections from the Prison Notebooks of Antonio Gramsci. Ed. and trans. Hoare, Q. and Nowell Smith, G. New York: International Publishers.

Hartmeyer, H. and Wegimont, L. (eds) (2016) Global Education in Europe Revisited: Strategies and structures, policy, practice and challenges (Erziehungswissenschaft und Weltgesellschaft 9). Münster: Waxmann.

Hayek, F.A. (1945) 'The use of knowledge in society'. The American Economic Review, 35 (4), 519-30.

Jones, B.G. (ed.) (2006) Decolonizing International Relations. Lanham, MD: Rowman \& Littlefield.

Jørgensen, M. and Phillips, L. (2002) Discourse Analysis as Theory and Method. London: SAGE Publications.

Koselleck, R. (2002) The Practice of Conceptual History: Timing history, spacing concepts. Stanford: Stanford University Press.

Latour, B. (1987) Science in Action: How to follow scientists and engineers through society. Cambridge, MA: Harvard University Press.

Morgenthau, H.J. (1946) Scientific Man vs Power Politics. Chicago: University of Chicago Press.

Rabinow, P. and Sullivan, W.M. (eds) (1979) Interpretive Social Science: A reader. Berkeley, CA: University of California Press.

Skinner, Q. (1969) 'Meaning and understanding in the history of ideas'. History and Theory, 8 (1), 3-53.

Taylor, C. (1971) 'Interpretation and the sciences of man'. Review of Metaphysics, 25 (1), 3-51.

Tuck, E. and Yang, W.K. (2012) 'Decolonization is not a metaphor'. Decolonization: Indigeneity, Education and Society, 1 (1), 1-40.

van Dijk, T.A. (1993) 'Principles of critical discourse analysis'. Discourse and Society, 4 (2), 249-83. 